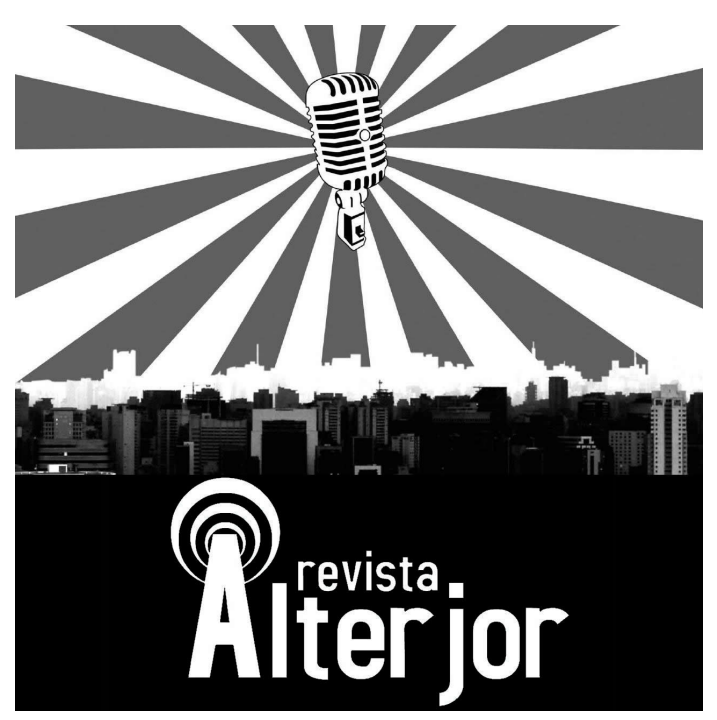

\title{
"MILAGRE DOS PEIXES": A CENSURA E A VOZ DE MILTON NASCIMENTO NA SOCIEDADE DO ESPETÁCULO BRASILEIRA
}

\author{
Emerson Ike Coan ${ }^{1}$
}

RESUMO: O artigo versa sobre a produção cultural de Milton Nascimento, com vistas a uma compreensão das características da sociedade brasileira contemporânea, numa investigação de seu processo histórico e na perspectiva da Sociedade do Espetáculo, em especial no contexto musical e político do Brasil em 1973, quando lançado o álbum "Milagre dos Peixes". Este álbum é uma obra de arte sobrevivente aos ataques da censura no período da ditadura militar.

PALAVRAS-CHAVE: MPB. Milton Nascimento. Milagre dos Peixes. Sociedade do Espetáculo. Ditadura militar.

ABSTRACT: The article discusses Milton Nascimento's cultural production, aiming at an understanding of the characteristics of contemporary Brazilian society in a research of its historical process and from the perspective of the Society of the Spectacle, especially in musical and political context of Brazil in 1973, when the album "Milagre dos Peixes" was released. This album is a work of art that survived censorship attacks during the military dictatorship.

KEYWORDS: MPB. Milton Nascimento. Milagre dos Peixes. Society of the Spectacle. Military dictatorship.

\footnotetext{
${ }^{1}$ Mestre em Comunicação pela Faculdade Cásper Líbero (FCSCL), na qual é Membro do Grupo de Pesquisa (CNPq) Comunicação e Sociedade do Espetáculo. Mestre em Filosofia e Teoria Geral do Direito pela Faculdade de Direito da Universidade de São Paulo (USP). E-mail: emersonike@hotmail.com
}

Revista ALTERJOR

Grupo de Estudos Alterjor: Jornalismo Popular e Alternativo (ECA-USP)

Ano 10 Volume 02 Edição $22 \quad$ Juho-Dezembro de 2020

Avenida Professor Lúcio Martins Rodrig̉ues, 443, Cidade Universitária, São Paulo, CEP: 05508-020 


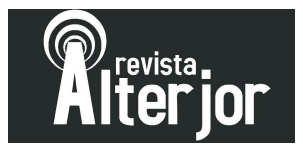

\section{Introdução}

Este artigo parte de um projeto de pesquisa maior acerca da produção cultural dos artistas que integraram o denominado "Clube da Esquina", na década de 1970, versa sobre o álbum "Milagre dos Peixes" de Milton Nascimento, de 1973, em seu contexto musical e político, com vistas a uma compreensão das características da sociedade brasileira contemporânea, numa investigação de seu processo histórico e na perspectiva da Sociedade do Espetáculo.

Os países subdesenvolvidos como o Brasil não foram analisados de forma detida por Guy Debord na sua obra “A Sociedade do Espetáculo". No entanto, dada a contemporaneidade na qual este livro foi escrito, em 1967, e considerando a relação de dependência do Brasil, em face dos países desenvolvidos, este estudo vislumbra a aplicação dos conceitos formulados por Guy Debord de poder espetacular concentrado e poder espetacular difuso na sociedade brasileira no período do regime militar, especificamente nos denominados "anos de chumbo" e de "milagre econômico", entre 1969 e 1974.

Pretende-se com esta investigação verificar, pelo método da pesquisa histórica, se a produção cultural de Milton Nascimento, quando do lançamento do mencionado álbum, se contrapôs a essas formas de poder espetacular concentrado e difuso.

O texto procura uma primeira contraposição estética ao sistema vigente a partir da elaboração da capa, da contracapa e dos encartes do álbum. Depois, toma o título - e a letra - "Milagre dos Peixes" como oposição à ideologia do "milagre econômico" ora propagada, atrelada aos rigores do processo "linha dura", estabelecido a partir do Ato Institucional n. ${ }^{\circ} 5$ de dezembro de 1968. Em razão da censura, com corte nas canções "Os escravos de Jó", "Hoje é dia de El-Rey" e "Cadê", o estudo avalia, a partir da reprodução das respectivas letras, os motivos pelos quais foram proibidas de serem cantadas, e o quanto as gravações, apenas com voz, efeitos vocais e instrumentação, conferiram a densidade sonora característica do álbum.

A pesquisa examina, por fim, se o álbum se revelou transformador na sociedade brasileira de então, sob os aspectos interligados da cultura ou da inovação na Música

Revista ALTERJOR

Grupo de Estudos Alterjor: Jornalismo Popular e Alternativo (ECA-USP)

Ano 10 Volume 02 Edição $22 \quad$ Juho- Dezembro de 2020

Avenida Professor Lúcio Martins Rodrig̉ues, 443, Cidade Universitária, São Paulo, CEP: 05508-020 


\section{Ateijor}

Popular Brasileira, da política ou da resistência ao regime autoritário, e do comportamento ou da contracultura.

\section{A sociedade do espetáculo brasileira}

Na edição de “A Sociedade do Espetáculo", em 1967, Guy Debord expõe que:

O espetáculo é o momento em que a mercadoria "ocupou totalmente" a vida social. Não apenas a relação com a mercadoria é visível, mas não se consegue ver nada além dela: o mundo que se vê é o seu mundo. A produção econômica moderna espalha, extensa e intensivamente, sua ditadura (Debord, 1997: 30).

Para a teoria crítica, a sociedade do espetáculo é um conceito histórico e corresponde a uma fase específica da sociedade capitalista, quando há uma interdependência entre o processo de acúmulo de capital e o processo de acúmulo de imagens. Significa dizer que não é um substituto para o conceito de sociedade capitalista nem é a própria sociedade dominada pelos meios de comunicação, particularmente pelos mecanismos de produção de imagens, como muitos confundem. É muito citada a tese de Debord: “O espetáculo não é um conjunto de imagens, mas uma relação social entre pessoas, mediada por imagens" (Debord, 1997: 14). Como explica Cláudio Novaes Pinto Coelho:

o espetáculo é um elemento articulador, ele estabelece mediações entre as várias dimensões da realidade social capitalista. A compreensão do papel desempenhado pelos meios de comunicação depende de uma investigação sobre as características da sociedade enquanto uma totalidade articulada internamente: o ponto de partida para o entendimento dessa totalidade são as relações sociais de produção. O conceito de sociedade do espetáculo, em Debord, está vinculado a uma interpretação materialista (marxista) da vida social (Coelho, 2006: 15).

A lógica da separação é, a par disso, um componente essencial das relações sociais capitalistas. Nesse atual estágio, a vida humana, isto é, social, é reduzida à aparência. Primeiro, o próprio trabalhador acredita que o valor de uma mercadoria não é uma consequência de seu tempo de trabalho socialmente necessário para a sua 


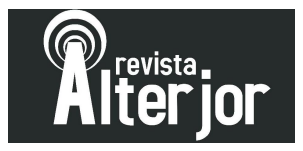

produção, mas algo que decorre da "natureza" do produto. Depois, os meios técnicos dominam de modo a influenciar (diga-se, alienar) a possibilidade de o indivíduo criar um distanciamento crítico.

Para esse efeito, a dimensão histórico-crítica do conceito de sociedade do espetáculo elaborado por Guy Debord requer a sua utilização sempre de forma particularizada; há, portanto, a necessidade de investigação das características das formações econômico-sociais "onde o conceito será aplicado, bem como de uma atualização permanente das reflexões feitas pelo autor" (Coelho, 2006: 22).

Embora os países de capitalismo tardio, periférico, dependente e subdesenvolvido, como o Brasil, não tenham sido analisados de forma detida por Debord, dada a contemporaneidade do livro "A Sociedade do Espetáculo", de 1967, considerando a relação de dependência em face dos países desenvolvidos, este estudo vislumbra a aplicação dos conceitos de poder espetacular concentrado e difuso no período da ditadura militar (1964-1985), especificamente nos "anos de chumbo" e de “milagre econômico/brasileiro", entre 1969 e 1974.

\section{As formas de poder espetacular no Brasil}

No livro "A Sociedade do Espetáculo", Debord distinguia duas formas de "poder espetacular", a saber, o "poder espetacular concentrado" (produzido nas ditaduras, fosse de direita ou de esquerda, como "capitalismo de Estado") e o "poder espetacular difuso" (em razão da americanização do mundo nas democracias ditas "burguesas").

Aqui no Brasil, em dezembro de 1968, com o Ato Institucional n. ${ }^{\circ}$ 5, o autoritarismo do governo dá curso a um processo "linha-dura", nos conhecidos "anos de chumbo", entre 1969 e 1974, sob a presidência do general Emílio Garrastazu Médici. O ato, que vigorou até 1978, concedeu ao Presidente plenos poderes para fechar por tempo ilimitado todo o Poder Legislativo, intervir em Estados e municípios, suspender por dez anos os direitos políticos de qualquer cidadão e cassar mandatos eletivos, demitir ou aposentar sumariamente funcionários públicos e juízes, suspender a garantia do "habeas corpus", efetuar prisões sem mandado judicial e decretar estado de sítio.

Revista ALTERJOR

Grupo de Estudos Alterjor: Jornalismo Popular e Alternativo (ECA-USP)

Ano 10 Volume 02 Edição $22 \quad$ Juho- Dezembro de 2020

Avenida Professor Lúcio Martins Rodrig̉ues, 443, Cidade Universitária, São Paulo, CEP: 05508-020 


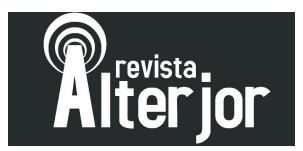

Como sustentado por Debord, "a ditadura tem que ser acompanhada de violência permanente" e, "onde o espetacular concentrado domina, a polícia também domina", sem contar a concentração do arbítrio "num só homem", que é a garantia da coesão totalitária, como "vedete absoluta que todos devem identificar-se magicamente, ou desaparecer”, “em acumulação primitiva acelerada pelo terror” (Debord, 1997: 43).

Por outro lado, à luz da Indústria Cultural, se as décadas de 1940 e 1950 podem ser consideradas como momentos incipientes de uma sociedade de consumo no Brasil, as décadas de 1960 e 1970 podem ser definidas pela consolidação de um mercado de bens culturais. A televisão se concretiza como veículo de massa em meados dos anos 1960, enquanto o cinema nacional somente se estrutura como indústria nos anos 1970. O mesmo pode ser dito de outras esferas da cultura popular de massa: indústria do disco, editorial, publicidade etc. (Ortiz, 1995: 113).

Desse modo, pode-se dizer que a consolidação do capitalismo monopolista no Brasil, com forte presença de empresas estrangeiras, deu-se no período do regime militar. Como analisa Renato Ortiz:

Certamente os militares não inventaram o capitalismo, mas 64 é um momento de reorganização da economia brasileira que cada vez mais se insere no processo de internacionalização do capital; o Estado autoritário permite consolidar no Brasil o "capitalismo tardio". Em termos culturais essa reorientação econômica traz consequências imediatas, pois, paralelamente ao crescimento do parque industrial e do mercado interno de bens materiais, fortalece-se o parque industrial de produção de cultura e o mercado de bens culturais (Ortiz, 1995: 113).

É o poder espetacular difuso "não perturbado do capitalismo moderno" (Debord, 1997: 43).

A ampliação da base material do exercício hegemônico burguês, com a ocupação do aparelho de Estado pelas Forças Armadas, deu-se no período do chamado "milagre econômico brasileiro", também entre 1969 e 1974, quando se pode dizer que ocorreu a consolidação do projeto de desenvolvimento econômico, associado e dependente do capital multinacional, norte-americano em especial, com o aumento do mercado 


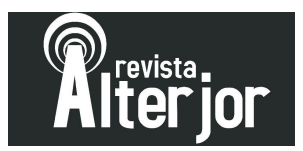

consumidor para bens de consumo duráveis. A isso se pode chamar de capitalismo monopolista de Estado (Coutinho, 2011: 61).

No contexto da Guerra Fria, o país era governado pelos militares por meio de atos institucionais (inspirados pela Doutrina de Segurança Nacional, voltada para a caça do "inimigo interno": a ideia de "comunista" como "terrorista"; "subversivo"), como estado de exceção, caracterizado pela restrição à liberdade de pensamento e de expressão, sob o lema de que "a segurança garante o desenvolvimento". A ideologia do "milagre econômico" era propagada por meio da televisão, colorida desde 1972, mediante símbolos de comodidade e de conforto da classe média, para a qual a renda era concentrada, sendo bem enfáticos os "slogans" da época: "Este é um país que vai pra frente", "Brasil, ame-o ou deixe-o", "Ninguém segura este país!". Não havia, porém, distribuição de renda para as camadas menos favorecidas, pois o modelo era de arrocho salarial e de exclusão social (Oliveira, 2013: 107-119²), cuja estratégia era "Fazer o bolo crescer para depois dividir", num processo de modernização excludente.

A identificação da presença simultânea de elementos do poder espetacular concentrado e do poder espetacular difuso parece ser apropriada para a caracterização das formações econômico-sociais capitalistas subdesenvolvidas, como a sociedade brasileira durante o período da ditadura militar, uma vez que:

Nesse período havia a presença simultânea de um Estado
economicamente intervencionista e promotor do "desenvolvimento", a
serviço da burguesia brasileira e multinacional, que concentrava o
exercício do poder político (e tentou, no início dos anos 1970,
transformar um general em "líder popular"), e de uma sociedade de
consumo em processo de constituição, promotora do culto das
mercadorias e da difusão social (especialmente pela Rede Globo de
Televisão) das práticas espetaculares (Coelho, 2006: 21-22).

O que não deixou de revelar uma contradição, porque o anseio de consumir livremente era tolhido pela ideologia da segurança nacional: "a censura dos produtos culturais entrava em choque com o próprio incentivo à indústria cultural promovido pela ditadura militar" (Coelho, 2004: 36).

\footnotetext{
${ }^{2}$ A primeira edição do texto é de 1972.
}

Revista ALTERJOR

Grupo de Estudos Alterjor: Jornalismo Popular e Alternativo (ECA-USP)

Ano 10 Volume 02 Edição $22 \quad$ Juho- Dezembro de 2020

Avenida Professor Lúcio Martins Rodrig̉ues, 443, Cidade Universitária, São Paulo, CEP: 05508-020 


\section{Aiteitior}

\section{O álbum "Milagre dos Peixes": a censura e a voz de Milton Nascimento}

A prática sistemática da censura, aliada a um claro terrorismo ideológico, pode ser considerada como a face aberta da "política cultural" vigente após 1968, ou seja, à posterior decretação do AI-5. Em razão disso, reinava um período de "cultura esvaziada" (Coutinho, 2011: 63).

De todas as manifestações culturais, pode-se dizer que a música popular era uma das mais visadas pela censura, uma vez que os festivais haviam projetado alguns artistas, conferindo-lhes popularidade. Para a ditadura, tais artistas estavam realizando um trabalho político contra o governo por meio de suas canções. Não por acaso, alguns deles foram torturados, exilados ou exilaram-se.

Nas palavras de Ana Maria Bahiana: "Milton é uma história diferente. [...] e o extraordinário 'Milagre dos Peixes', prova clara de como os rigores de uma situação extrema podem extrair da pedra bruta a mais pura luz" (Bahiana, 2006: 49). Na verdade, "foi um sobrevivente notável de um dos ataques mais raivosos da censura a uma obra de arte nesse ano de 1973" (Maciel, 2013: 256).

Em primeiro lugar, o álbum chama a atenção pelo formato de sua embalagem, composta de um pôster com três dobraduras. Na capa, existe a imagem em close de uma mão envolvendo um bebê. Na contracapa, há uma foto de Milton quando criança com roupa de marinheiro. Dentro dessa embalagem se alojam um LP, um compacto e cinco encartes em cores chamativas, contendo as fichas técnicas. O projeto da produção gráfica do álbum é de Noguchi, e as fotos são deste (capa) e de Ronaldo Cientista (contracapa).

Já na capa, na contracapa e nos encartes coloridos, veem-se traços de oposição de "Milagre dos Peixes" ao "milagre econômico". Além da referência ao milagre da multiplicação bíblico, veem-se as cores de outra realidade possível, e o bebê e a criança, assim como o título do álbum, estão como signos de "fecundidade, prosperidade e da renovação da vida; sempre associado à regeneração humana e ao nascimento de um outro tempo" (Martins, 2009: 167). 


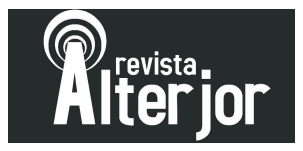

A letra de "Milagre dos Peixes" (M. Nascimento/Fernando Brant) é bastante enfática quanto a essa contraposição:

Eu vejo esses peixes e vou de coração/Eu vejo essas matas e vou de coração/À natureza//Telas falam colorido/De crianças coloridas/De um gênio, televisor/E no andor de nossos novos santos/O sinal de velhos tempos:/Morte, morte, morte ao amor//Eles não falam do mar e dos peixes/Nem deixam ver a moça, pura canção/Nem ver nascer a flor/Nem ver nascer o sol/Eu apenas sou um a mais, um a mais/A falar dessa dor, a nossa dor//Desenhando nessas pedras/Tenho em mim todas as cores/Quando falo coisas reais/E num silêncio dessa natureza/Eu que amo meus amigos/Livre, quero poder dizer:/Eu tenho esses peixes e dou de coração/Eu tenho essas matas e dou de coração

De início, nota-se uma postura contracultural, na oposição à racionalização da vida social pelo Estado e na relação homem/natureza.

Sobre isso:

No Brasil, a contracultura foi um movimento social que procurou romper com a modernização da sociedade brasileira posta em prática de forma autoritária pela ditadura militar, estabelecida no país com o golpe de 1964. Os membros dos governos militares consideravam o Estado a encarnação da racionalidade, cabendo às suas instituições (em especial as que compõem o Poder Executivo) organizar e controlar as diferentes dimensões da vida social, tendo em vista a promoção do desenvolvimento econômico. De acordo com essa visão de mundo, o Estado é o ator principal (o sujeito) da vida social (Coelho, 2005: 41).

A questão da relação homem/natureza,

que foi um dos temas centrais do contraculturalismo, emergiu no contexto da exacerbação antitecnológica que dominou o movimento, em decorrência da crítica à sociedade industrial e "de consumo", ou "plastic society", que levava a humanidade a cometer crimes contra si mesma. [...] Era como se os jovens do mundo ocidental, especialmente os hippies, estivessem redescobrindo o milagre diário da natureza (Risério, 2005: 27).

A letra começa com a marca da subjetividade (abertura para o mundo), que vê "peixes" e "matas" e vai de "coração" (emoção) "à natureza". Depois, passa pela observação de que "eles" (militares) não falam do "mar" e dos "peixes", nem deixam 


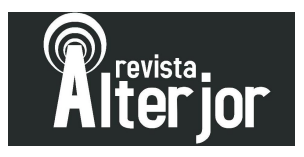

ver "a moça, pura canção", nem deixam ver "nascer a flor", nem ver "nascer o sol”. Até que, ao final, há, a partir dessa postura de denúncia e de resistência, esperança de nascimento de outro tempo ("livre"), de recuperação do contato com a natureza ("eu tenho peixes e matas”), a qual poderá ser partilhada (doada/multiplicada) com todos.

Em face da TV colorida como principal instrumento de veiculação da propaganda do regime autoritário, e um dos sinais utilizados para indicar o avanço econômico e tecnológico do país, a letra da música não deixa também de mostrar o período de repressão contra os descontentes e de desigualdade social, o outro lado da realidade brasileira.

É interessante observar o contraste estabelecido entre o que os militares (não) falam e não deixam ver e o que o cantor/indivíduo fala e vê. Eles, como Estado "racional" opressor, "não falam do mar e dos peixes", "nem deixam ver nascer a flor, nem ver nascer o sol”, o que é relativo à natureza (que o indivíduo vê com os próprios olhos). Sequer "deixam ver a moça, pura canção", o que é indicador do que é instintivo, portanto, natural. As telas da TV colorida falam daquilo que é relacionado à propaganda exibida pelo regime, "no andor de nossos novos santos", as imagens propagandísticas produzidas sobre a economia burocrática pelo "novo santo"/general/“líder-popular", como vedete absoluta do espetacular concentrado. O cantor/indivíduo é "um a mais, um a mais" a falar do "sinal de velhos tempos: morte, morte, morte ao amor", em razão da restrição à liberdade de pensamento e de expressão, num cotidiano de censura, exílio, torturas, mortes e desaparecimentos ${ }^{3}$, e da dor, a dor do povo, também relacionada à exclusão social. Ele, "desenhando nas pedras", forma primitiva de comunicação, tem em si "todas as cores" ao falar de "coisas reais", diferentes das exibidas pela televisão.

O álbum sofreu vários cortes pela censura. Houve corte praticamente na íntegra nas letras das músicas “Os escravos de Jó” e "Hoje é dia de El-Rey”, e na íntegra na de "Cadê". No entanto, nos encartes é possível notar o protesto, pois deixam claro que as músicas possuíam letras, uma vez que as fichas técnicas, as mais detalhadas da discografia brasileira até aquele ano (Duarte, 2009: 182), traziam os créditos (“letra de")

\footnotetext{
${ }^{3}$ Cf. "Brasil: Nunca Mais", 1986.
} 


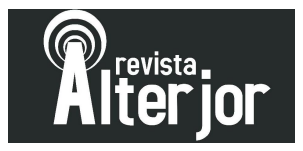

aos respectivos letristas: Fernando Brant, Márcio Borges e Ruy Guerra. Milton preferiu não pedir aos letristas que fizessem, como era comum na época, "retoques" nas letras para poder gravá-las.

Na gravação do disco, Milton, em vez de ser apenas cantor, utiliza vocalises, o falsete como alternativa timbrística, além de fazer uso incisivo de gritos, sussurros e outros efeitos de voz para expor, por meio de uma densidade sonora (interpretativa e instrumental), aquilo que não podia ser dito mediante palavras. A voz é utilizada como instrumento musical. Diz o produtor do álbum, Fernando Brant:

De repente - pensamos - já que não vai ter letra mesmo, o negócio é carregar no canto, protestar, dar o recado através da voz. Lembro-me que as gravações eram muito emocionadas, muito fortes. O Bituca quis colocar para fora tudo aquilo que estavam impedindo que ele dissesse com palavras (Mattos, 2006: 70).

Das onze músicas do álbum, três letras não sofreram cortes - "Milagre dos Peixes", "Sacramento" (Nelson Ângelo/M. Nascimento) e "Pablo" (M. Nascimento/Ronaldo Bastos) - e cinco eram para ser gravadas somente com a melodia ou instrumentais, todas de Milton Nascimento - "Carlos, Lúcia, Chico e Tiago (Eu sou uma preta velha aqui sentada ao sol)", "A chamada", "Pablo no 2 (Festa)", "Tema dos deuses" e "A última sessão de música".

Com a censura das três letras mencionadas, o álbum ganhou um aspecto mais instrumental, ou seja, fora do padrão estético e mercadológico do poder espetacular difuso.

Sobre "Os escravos de Jó” (M. Nascimento/F. Brant), a música já era conhecida com outra letra e com o nome de "O homem da sucursal", gravada num compacto duplo $^{4}$ de 1970, com a trilha sonora do filme "Tostão: a fera de ouro", de Ricardo Gomes Leite e Paulo Laender. A letra submetida ao órgão censor como "Escravos de Jó", inspirada em jogos infantis, foi tida como "Contestação política. Sátira e protesto. Cordão pornográfico" (Diniz, 2017: 149).

\footnotetext{
${ }^{4}$ As canções foram incluídas na versão em CD do álbum “Milton”, de 1970. 


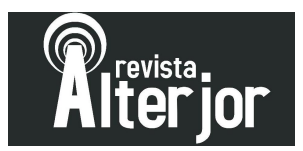

Dizem que está bom/Dizem que está bom/Difícil ver um troço pior/Mas dizem nós estar na melhor/Se viver, eu sou réu/Se morrer, é só véu/Melhor é colher favos de mel/Saio do trabalho ei/Volto para casa ei/Não lembro de canseira maior/Em tudo é o mesmo suor/Ó, bela Rapunzel/Seu jovem menestrel/Precisa de um pouco de amor/Mas que não faça muito calor/A vaca Vitória lambeu, lambeu/Mexeu, mexeu e remexeu/Quem falar primeiro, quem falar primeiro/Vai ser aquele que comeu/Gritos de alegria, de histeria/E luzes e bombas/Bomba cai do céu/(Que fedor!)/Saio do trabalho ei/Volto para casa ei/Não lembro de canseira maior/Em tudo é o mesmo suor

A letra é de fato satírica, sobretudo pela analogia de "Vaca amarela" (brincadeira infantil do folclore brasileiro que consiste num desafio para ver quem fica calado por mais tempo) ao regime político - "A vaca Vitória lambeu, lambeu/Mexeu, mexeu e remexeu/Quem falar primeiro, quem falar primeiro/Vai ser aquele que comeu/Gritos de alegria, de histeria/E luzes e bombas/Bomba cai do céu/(Que fedor!)” -, embora não fosse pertinente o "condão pornográfico" pela utilização da palavra "vaca". A contestação surge já no início da letra: "Dizem que está bom/Dizem que está bom/Difícil ver um troço pior/Mas dizem nós estar na melhor/Se viver, eu sou réu/Se morrer, é só véu/Melhor é colher favos de mel”.

Seu registrou foi instrumental, pois apenas a última estrofe foi permitida pelo Serviço de Censura de Diversões Públicas da Polícia Federal de ser cantada por Clementina de Jesus ("Saio do trabalho e/Volto para casa e/Não lembro de canseira maior/Em tudo é o mesmo suor"). A música ganhou consistência sonora, ruidosa até, e seguiu provocadora ao unir coro, efeitos vocais - como gritos e falsete - e o volume alto da percussão, a cargo de Naná Vasconcelos, com seu marcante berimbau, inclusive. Ao longo do disco, a participação deste é notável.

Neste disco, a propósito, a busca de uma sonoridade mais "suja" fica mais explícita, como explica Ivan Vilela:

Percebemos, desde a primeira música, a proximidade com o som das festas de rua, os congados e moçambiques mineiros, uma certa profusão sonora aparentemente desordenada (só aparentemente) e com muita musicalidade. O pulso mesmo da África que não veio pela via do samba. [...] Nesse álbum consolida-se a importância e independência da percussão a partir do volume que ela ganha nas

Revista ALTERJOR

Grupo de Estudos Alterjor: Jornalismo Popular e Alternativo (ECA-USP)

Ano 10 Volume 02 Edição $22 \quad$ Juho- Dezembro de 2020

Avenida Professor Lúcio Martins Rodriǵues, 443, Cidade Universitária, São Paulo, CEP: 05508-020 


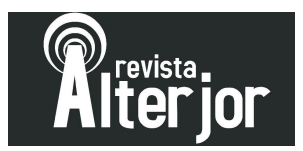

gravações. Em "Milagre dos peixes", vê-se a coragem de se fazer uma música de alta qualidade, um trabalho musical, porém, repleto de experimentalismos vocais, percussivos, enfim, sonoros (Vilela, 2010: 23-24).

Anos depois, a canção foi gravada com outra letra e com novo nome, “Caxangá”, por Elis Regina, em seu disco "Elis”, de 1977.

Sempre no coração/Haja o que houver/A fome de um dia poder/Morder a carne dessa mulher/Veja bem, meu patrão/Como pode ser bom/Você trabalharia no sol e eu/Tomando banho de mar/Saio do trabalho e/Volto para casa e/Não lembro de canseira maior/Em tudo é o mesmo suor//Luto para viver/Vivo para morrer/Enquanto minha morte não vem/Em tudo é o mesmo suor//Luto para viver/Vivo para morrer/Enquanto minha morte não vem/Eu vivo de brigar contra o rei//Em volta do fogo todo/Mundo abrindo o jogo/Com tudo que tem pra contar//Casos e desejos coisas/Dessa vida e da outra/Mas nada de assustar/Quem não é sincero sai da brincadeira/Correndo, pois pode se queimar/Queimar//Saio do trabalho e/Volto para casa e/Não lembro de canseira maior/Em tudo é o mesmo suor. ${ }^{5}$

O conteúdo permaneceu bem contundente em relação aos padrões estabelecidos.

De início, a subjetividade/emoção se opõe à objetividade/razão, pois é dito: "Sempre no coração/Haja o que houver", com prevalência do instintivo/natural: "A fome de um dia poder/Morder a carne dessa mulher”. Depois a mudança radical da relação exploratória entre patrão/empregado: "Veja bem, meu patrão/Como pode ser bom/Você trabalharia no sol e eu/Tomando banho de mar". Em seguida, a oposição ao regime vigente: "Luto para viver/Vivo para morrer/Enquanto minha morte não vem/Eu vivo de brigar contra o rei", em que este "rei" é o general no poder, e a luta segue num regime que mata os "subversivos". No campo de batalha, "Em volta do fogo todo/Mundo abrindo o jogo/Com tudo que tem pra contar", subsistem "Casos e desejos coisas/Dessa vida e da outra/Mas nada de assustar", como expressão do sincretismo religioso (a música tem ritmo africano). Por fim, a referência ao título da música, a brincadeira ("Escravos de Jó”), "Quem não é sincero sai da brincadeira/Correndo, pois pode se queimar/Queimar", aludindo a que todo jogo possui regras próprias, e a ditadura quebrou as regras do

\footnotetext{
${ }^{5}$ Maciel, 2012: 24-25.
}

Revista ALTERJOR

Grupo de Estudos Alterjor: Jornalismo Popular e Alternativo (ECA-USP)

Ano 10 Volume 02 Edição $22 \quad$ Juho- Dezembro de 2020

Avenida Professor Lúcio Martins Rodrig̉ues, 443, Cidade Universitária, São Paulo, CEP: 05508-020 


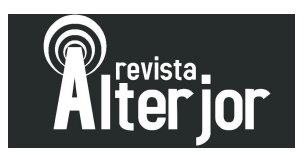

regime democrático. Sobre isso, tanto o trabalho quanto a resistência ao sistema impõem uma "canseira maior" e "Em tudo é o mesmo suor".

Já na letra de "Hoje é dia de El-Rey" (M. Nascimento/Márcio Borges), apenas a expressão "Filho meu/Meu filho" passou pela censura. Segundo o próprio letrista, Márcio Borges: "Eu me lembro que os censores devolveram a letra toda rabiscada com pincel atômico. Sobraram apenas duas palavras, que eles não rabiscaram. Aí nós cantamos essas duas palavras" (Mattos, 2006: 145).

Filho - Não pode o noivo mais ser feliz/Não pode viver em paz com seu amor/Não pode o justo sobreviver/Se hoje esqueceu o que é bemquerer/Rufai tambores saudando El-Rey/Nosso amo e senhor e dono da lei/Soai clarins, pois o dia do ódio/E o dia do não vêm com (são por) El-Rey//Pai - Filho meu, ódio você tem,/ Mas alguém quer provar o seu amor (Mas El-Rey quer viver só de amor)/Sem clarins e sem mais tambor/ Nenhum rei vai mudar a velha dor (Vá dizer: nosso dia é de amor)//Filho - Juntai as muitas mentiras/Jogai os soldados na rua/Nada sabeis desta terra/Hoje é o dia da lua//Pai - Filho meu, cadê teu amor/Nosso Rey está sofrendo a sua dor//Filho - Leva daqui tuas armas/Então cantar poderia?/Mas nos teus campos de guerra/Ontem (Hoje) morreu poesia//Ambos (coro) - El-Rey virá calar (salvar).../Pai - Meu filho, você tem razão/Mas acho que não é em tudo/Se a gente (o mundo) fosse o que pensa/Estava tudo no mesmo lugar/Medo ninguém (Pai você não) tinha agora/E tudo podia mudar (E hoje pior ia estar)//Filho - Matai o amor, pouco importa/Pois (Mas) outro haverá de surgir/O mundo é pra frente que anda/Mas tudo está como está/Hoje então e agora/Pior não pode (podia) ficar//Ambos (coro) - Largue o seu dono/Viaje noutra poesia (E procure nova alegria)/Se hoje é triste e coragem (saudade) pode matar/Vem, amizade não pode/Ser com maldade/Se hoje é triste a verdade/Empurre a porta sombria (Procure nova poesia)/Encontre (Procure) nova alegria/(Para) amanhã. ${ }^{6}$

A letra reproduzida acima é a vetada pela censura (Diniz, 2017: 144-145), com acréscimos, entre parênteses, da divulgada no CD "Milagre dos Peixes" (Maciel, 2012).

Por causa dela, Milton foi "convidado" a prestar depoimento no DOPS (Departamento de Ordem Política e Social) (Borges, 1996: 305; Duarte, 2009: 182). ${ }^{7}$ Os

\footnotetext{
${ }^{6}$ Maciel, 2012: 36-37.

7 Tempos depois, Milton foi proibido de pisar em São Paulo e de ter contato com o filho Pablo, sob pena de sequestro deste (Duarte, 2009: 188).
}

Revista ALTERJOR

Grupo de Estudos Alterjor: Jornalismo Popular e Alternativo (ECA-USP)

Ano 10 Volume 02 Edição $22 \quad$ Juho- Dezembro de 2020

Avenida Professor Lúcio Martins Rodrig̉ues, 443, Cidade Universitária, São Paulo, CEP: 05508-020 


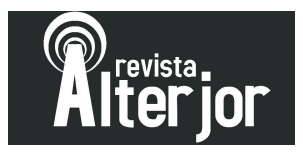

motivos alegados pelos censores para proibir a letra, segundo Márcio Borges, foram que ela "incitava à subversão e à desobediência civil" (Mattos, 2006: 146). A anotação da censora foi "Conteúdo nitidamente político" (Diniz, 2017: 144).

Inspirada na "Suíte dos Pescadores", de Dorival Caymmi (que participaria da gravação como o "pai", se não houvesse o corte da letra pela censura), a música tem a estrutura de um diálogo entre pai e filho (que seria interpretado por Milton), versando sobre o conflito de gerações. Sobre a censura, disse Bituca: “- Vou gravar de qualquer jeito. Vou botar no som tudo o que eles tiraram na letra. Eles não ver comigo" (Borges, 1996: 306).

O conflito de gerações relatado não se trata apenas do relativo à tradição do pai e à transformação do filho, mas também do relativo àqueles que apoiaram - ou se conformaram com - o golpe civil-militar de 1964 e àqueles que a ele se opuseram. O diálogo ficou registrado no contraponto entre Sirlan e Milton.

O discurso do filho é no sentido de não se poder "mais ser feliz", "viver em paz", “o justo sobreviver", se foi esquecido "o que é bem-querer". Devem-se rufar tambores "saudando El-Rey", "amo e senhor e dono da lei”, o general-presidente do país. Devem-se soar clarins, "pois o dia do ódio/E o dia do não são por El-Rey”. Fala das "muitas mentiras", dos "soldados na rua", de levar "daqui tuas armas", "dos campos de guerra", da morte da poesia e do amor. Fala que outro amor "haverá de surgir", que "o mundo é pra frente que anda/mas tudo está como está", e que, naquele momento, "pior não pode ficar". A voz do filho, mais aguda, colocada por Milton, é a de quem está reivindicando algo, exaltado até. O ritmo, num primeiro momento, é galopante; depois, tem marcação mais dramática. O sax nesta parte é tocado por Paulo Moura.

O discurso do pai é no sentido de que o filho tem ódio, "mas alguém quer provar seu (El-Rey quer viver só de) amor/Sem clarins e sem mais tambor”. Que apesar da ditadura, se o mundo fosse como ele pensa, "estava tudo no mesmo lugar/medo ninguém (pai não) tinha agora/e tudo podia mudar (hoje pior ia estar)”. A voz do pai, mais grave, colocada por Sirlan, é de quem quer conformar, serenamente, o 


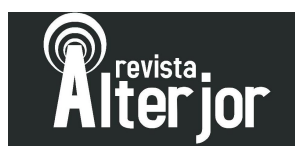

reivindicante. O violão, no início, é dedilhado, e, após, é tocado de outra forma. O sax, nesta parte, é tocado por Nivaldo Ornelas.

O discurso de ambos (coro) é de início, o de que "El-Rey virá calar (salvar)...", por parte do pai, na crença de que o regime militar irá propiciar o desenvolvimento do país, e, por parte do filho, na crença de que desenvolvimento pode haver sem repressão e sem pobreza, ou seja, com um governo que restitua a democracia e a inclusão social. No final, porém, eles estão de acordo (o filho convence o pai) em largar o "dono", procurar "nova alegria", constatando que: "se hoje é triste e coragem (saudade) pode matar", a "amizade não pode/ser com maldade", e que, "se hoje é triste a verdade", é preciso "empurrar a porta sombria (procurar nova poesia)', procurar "nova alegria/(para) amanhã...”, o dia que virá. No primeiro momento, as vozes e os efeitos sonoros (orquestra/sax), ruidosos, remetem a um ambiente de discórdia, ao passo que, no segundo momento, o ritmo da música muda, e faz reportar-se a um clima de suavidade, com orquestração e solo de sax, tocado por Nivaldo Ornelas. O arranjo de orquestra é de Wagner Tiso, com regência de Paulo Moura.

Por fim, a letra de "Cadê" (M. Nascimento/Ruy Guerra):

\begin{abstract}
Meu príncipe encantado/Meu príncipe encantado (cansado)/Cadê tuas botas de sete léguas?/E a Tilim de Peter Pan?/E tua esperança Branca de Neve?/Cadê, quem levou?/Quem levou?/Meu príncipe esperado/Meu príncipe suado/Que é do beijo da Bela Adormecida?/E a espada de condão?/E o País Maravilhoso de Alice?/Cadê, quem levou?/Quem levou?/Meu príncipe assustado/Meu príncipe queimado/Corta a noite escura desta floresta/Mata o fogo do dragão/Traz da lenda os jogos de nossa festa/Pra eu poder brincar/ Dançar/Falar/Rodar/Pular/Ficar/Zelar/Chegar/Parar/Cruzar/Sorrir/E dormir (e sorrir)
\end{abstract}

As alegorias contidas na letra dessa música também incomodaram os censores do regime militar. A letra foi vetada porque o censor viu nela "Ironia política. Contestação" e assinalou para a sequência de verbos no infinitivo ao final: "(o que diz êle não ser permitido)" - "sic" (Diniz, 2017: 154).

A sucessão de interrogações descreve o "príncipe encantado" e "esperado" que passa por uma batalha (contra o sistema vigente) em que se cansa, sua e se queima. Ao 


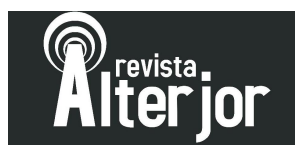

longo dessa trajetória do herói (no período da ditadura militar), é de se perguntar que conto de fadas (contado pelos detentores do poder) é esse? Se, na realidade, cadê "tuas botas de sete léguas? E a Tilim de Peter Pan? E tua esperança Branca de Neve? Do beijo da Bela Adormecida? E a espada de condão? E o País Maravilhoso de Alice? Cadê, quem levou? Quem levou? Cadê, quem levou? Quem levou?" (a liberdade que havia no país). Perguntas do expectador desse acontecimento todo, que ao final pede ao herói que vença o inimigo e traga novos tempos: "Corta a noite escura desta floresta, Mata o fogo do dragão, Traz da lenda os jogos de nossa festa, Pra eu poder brincar e sorrir”.

Milton grava a música com entonação diferenciada quando a frase é afirmativa e quando é interrogativa, com as respectivas alterações rítmicas. $\mathrm{O}$ uso do falsete é também notável nessa música. Há um acento jazzístico, principalmente no final, com o solo de Wagner Tiso ao piano elétrico.

O esgotamento de Milton por força da censura e por ter de colocar na voz a emoção que não pôde exprimir em palavras é manifestado em "A chamada", uma das músicas "somente com melodia", na qual, em meio às vozes, ele diz "Eu to cansado", "Me salva", "Eu to cansado", logo após a metade da faixa.

\section{Considerações finais}

Este artigo versou sobre o álbum "Milagre dos Peixes" de Milton Nascimento, de 1973, com vistas a uma compreensão das características da sociedade brasileira contemporânea, numa investigação de seu processo histórico e na perspectiva da Sociedade do Espetáculo. Neste estudo foram aplicados os conceitos de Guy Debord sobre as formas de poder espetacular concentrado e poder espetacular difuso, ao assumirem uma feição mista no período do regime militar dos "anos de chumbo" e do “milagre econômico", entre 1969 e 1974.

Verifica-se que, já na capa, na contracapa e nos encartes coloridos, existem traços de oposição de "Milagre dos Peixes" ao "milagre econômico", base de sustentação ideológica dos rigores do processo "linha dura" estabelecido a partir do AI n. ${ }^{\circ} 5$ de 1968. Além da referência ao milagre da multiplicação bíblico, veem-se as cores 


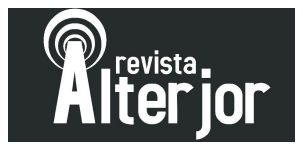

de outra realidade possível, e o bebê e a criança, assim como o título do álbum, apresentam-se como signos de renovação da vida, de regeneração humana e de nascimento de outro tempo.

Constata-se que a letra da música enfatiza essa contraposição a partir de uma postura contracultural, principalmente na relação homem/natureza. Em face da TV colorida como principal instrumento de veiculação da propaganda do regime autoritário (componente do espetacular concentrado) e um dos sinais utilizados para indicar o avanço econômico e tecnológico do país (componente do espetacular difuso), a letra da música não deixa de se opor ao período de repressão contra os descontentes e de desigualdade social: o outro lado da realidade brasileira.

Houve corte pela censura (componente do espetacular concentrado) praticamente na íntegra das letras das músicas "Os escravos de Jó” e "Hoje é dia de El-Rey”, e na íntegra de "Cadê". No entanto, nos encartes é possível notar o protesto, pois fica claro que as músicas possuíam letras, uma vez que as fichas técnicas traziam os créditos ("letra de") aos respectivos letristas. Em "Hoje é dia de El-Rey", a manutenção da expressão "meu filho/filho meu" deixa evidente que houve censura. Os conteúdos censurados são bem contundentes em relação aos padrões estabelecidos.

Observa-se que, na gravação do disco, Milton Nascimento, num experimentalismo sem precedente, em vez de ser apenas cantor, utiliza vocalises, o falsete como alternativa timbrística, além de fazer uso incisivo de gritos, sussurros e outros efeitos de voz para expor aquilo que não podia ser dito mediante palavras. A voz é utilizada como instrumento musical.

A utilização de ruídos, percussão, a confluência de ritmos (regional/afro/latinoamericano) com o jazz rock/“fusion" e a orquestração acentuam a evolução técnica, no padrão "Clube da Esquina" de ser - uma produção coletiva aberta a todos os músicos participantes -, e a consolidação do estilo "Milton Nascimento" para a música mundial.

É possível ver, apesar da censura nas letras das músicas, a preservação da autonomia criativa dos artistas na produção sonora de um álbum na Música Popular Brasileira do início dos anos 70 , de modo que ainda não havia se cristalizado numa

\footnotetext{
Revista ALTERJOR

Grupo de Estudos Alterjor: Jornalismo Popular e Alternativo (ECA-USP)

Ano 10 Volume 02 Edição $22 \quad$ Juho- Dezembro de 2020

Avenida Professor Lúcio Martins Rodriģues, 443, Cidade Universitária, São Paulo, CEP: 05508-020
} 


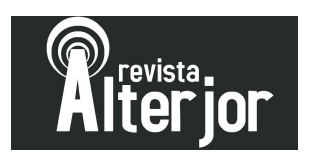

fórmula padronizada, sob o controle da indústria cultural (componente do espetacular difuso).

Por fim, tem-se que houve transformações em três aspectos interligados. A contracultura, quanto aos comportamentos relacionados à subjetividade, à emoção, à liberdade de expressão e à relação homem/natureza em face do Estado "racional" opressor. A resistência ao regime político ditatorial e excludente, a fim de que outro se colocasse no lugar e resgatasse a liberdade perdida e possibilitasse a inclusão social. E a inovação cultural na Música Popular Brasileira, em que a utilização da voz promoveu uma densidade sonora (interpretativa e instrumental) ao álbum, a qual não correspondia aos padrões conhecidos na sociedade brasileira do momento.

\section{Referências bibliográficas}

BAHIANA, Ana Maria. Nada será como antes: MPB anos 70 - 30 anos depois. Ed. revista - Rio de Janeiro: Editora SENAC Rio, 2006.

BORGES, Márcio. Os sonhos não envelhecem: Histórias do Clube da Esquina. São Paulo: Geração Editorial, 1996.

Brasil: Nunca Mais. ARNS, Dom Paulo Evaristo (prefácio). Petrópolis/R. J.: Vozes, 1986.

COELHO, Cláudio Novaes Pinto. "A indústria cultural, a publicidade e a consolidação da hegemonia burguesa no Brasil”. Communicare, v. 4, n. 2, São Paulo: Cásper Líbero, pp. 29-39, 2004.

"A Contracultura: o outro lado da modernização autoritária". In: Anos 70: Trajetórias. São Paulo: Iluminuras, p. 39-44, 2005.

"Em torno do conceito de sociedade do espetáculo". In: COELHO, C.N.P.; CASTRO, V. J. de (Orgs.). Comunicação e sociedade do espetáculo. São Paulo: Paulus, p. 13-30, 2006.

COUTINHO, Carlos Nelson. Cultura e Sociedade no Brasil. Ensaios sobre Ideias e Formas. São Paulo: Expressão Popular, 2011.

DEBORD, Guy. A sociedade do espetáculo. Rio de Janeiro: Contraponto, 1997.

DINIZ, Sheyla Castro. “...De tudo que a gente sonhou”: amigos e canções do Clube da Esquina. São Paulo: Intermeios, Fapesp, 2017.

\footnotetext{
Revista ALTERJOR

Grupo de Estudos Alterjor: Jornalismo Popular e Alternativo (ECA-USP)

Ano 10 Volume 02 Edição $22 \quad$ Juho- Dezembro de 2020

Avenida Professor Lúcio Martins Rodrig̉ues, 443, Cidade Universitária, São Paulo, CEP: 05508-020
} 


\section{ARtejior}

DUARTE, Maria Dolores Pires do Rio. Travessia: a vida de Milton Nascimento. $3^{\mathrm{a}}$ ed. - Rio de Janeiro: Record, 2009.

MACIEL, Luiz. Milagre dos peixes. São Paulo: Abril (Abril Coleções), 2012.

"A arte de colocar no som o que a censura tirou da letra... e fazer um disco revolucionário". In: ALBUQUERQUE, C. (Org.). 1973. O ano que reinventou a MPB. A história por trás dos discos que transformaram a nossa cultura. Rio de Janeiro: Sonora Editora, p. 255-264, 2013.

MARTINS, Bruno Viveiros. Som Imaginário: a reinvenção da cidade nas canções do Clube da Esquina. Belo Horizonte: Editora UFMG, 2009.

MATTOS, Paulo César Vilara de. Palavras Musicais: letras, processo de criação, visão de mundo de 4 compositores brasileiros (Fernando Brant, Márcio Borges, Murilo Antunes e Chico Amaral). Entrevistas. Belo Horizonte: s. ed., 2006.

NASCIMENTO, Milton. Milagre dos Peixes. Rio de Janeiro: EMI-Odeon, 1973. 1 LP e 1 compacto.

OLIVEIRA, Francisco. Crítica à razão dualista: o ornitorrinco. São Paulo: Boitempo, 2013.

ORTIZ, Renato. A moderna tradição brasileira. Cultura brasileira e indústria cultural. São Paulo: Brasiliense, 1995.

RISÉRIO, Antonio. "Duas ou três coisas sobre a contracultura no Brasil". In: Anos 70: Trajetórias. São Paulo: Iluminuras, p. 25-30, 2005.

VILELA, Ivan. "Nada ficou como antes". Revista USP nº 87, São Paulo, set./nov., p. $14-27,2010$. 